\title{
EDITORIAL
}

\section{Tribute to the late Emeritus Professor Lester A Mitscher}

The Journal of Antibiotics (2016) 69, 580; doi:10.1038/ja.2016.83

$\mathrm{I}$ $\mathrm{t}$ is an honor and privilege for me to pay tribute to the late Emeritus Professor Lester A Mitscher, an outstanding scientist, educator and advocate for the disciplines of natural products and all forms of medicinal chemistry, and their key role in the discovery and development of novel anti-infective and anticancer agents. Like so many scientists working in these fields, I was greatly saddened when I learned of his passing on May 8th, 2015. Barely 3 months earlier, I had been in contact with him concerning the pivotal role he played in the early 1990s in changing the name of the journal of the American Society of Pharmacognosy (ASP) from Lloydia to the Journal of Natural Products (JNP), and in guiding its transition to becoming a joint publication of the ASP and the American Chemical Society (ACS). At the time, Les was President of the ASP, and it was his leadership and wise counsel that led to the appointment of Professor A Douglas Kinghorn as Editor-in-Chief of JNP, which, under his inspiring leadership, has risen to become one of the leading natural products journals. Les was a long-time member of the ASP, and in 2007 he received the Society's highest award, the Norman R Farnsworth Research Achievement Award, and was also elected as a Fellow. His extensive knowledge and expertize in the areas of natural products and medicinal chemistry, and his outstanding achievements in drug discovery and development, were an inspiration to his many friends and colleagues, and he served as a wonderful role model and mentor to a host of young aspiring chemists, eager to explore the riches of Nature as a source of novel medicinal agents through multidisciplinary, collaborative research, embracing both the public and private sectors.

Les was most generous in sharing his knowledge and expertize as a service to the scientific and biomedical communities, both nationally and globally. In addition to his Presidency of the ASP, he also served in leadership positions in the ACS Medicinal Chemistry Division (1972-1982), and at various times, was on the editorial boards of 20 journals, including The Journal of Antibiotics (JA) since 1974. He was consultant to numerous companies, including 37 years with Abbott Laboratories, and was Chairman or a member of NIH study sections dealing with medicinal chemistry and natural products (1976-1984), as well the American Cancer Society Hematology and Chemotherapy
Study Section (1987-1991). On the international front, Les served on various committees of the International Union of Pure and Applied Chemistry (Medicinal Chemistry, Education, Training and Development) from 1991-2002, and was a member of the International Organization for Chemistry in Development since 1986, serving as Chair of the Medicinal Chemistry Section from 1996 to his passing last year. He and his wife, Betty, volunteered their services to professional organizations in Africa and Central and South America, lecturing on contemporary scientific methods and demonstrating methods in the laboratory. Les also mentored groups of professors at local universities updating them on relatively simple techniques, which can be applied to perform in-country research developing suitable and affordable medicines for the treatment of AIDS and tuberculosis. Of particular note was his service as a Consultant and Senior Advisory Board member of the Gates Global Alliance for Tuberculosis Drug Development since 2004 .

As stated by the organizers of the symposium that was held in 2011 at the University of Kansas celebrating his 80th birthday, 'it's hard to overstate the personal and scientific impact that Les Mitscher has had on medicinal chemistry and his students and postdocs'. I might add that this impact has been felt worldwide in the area of natural products drug discovery and development, and our community has lost a 'wonderful, kind human being'. The many awards and honors he received bear testimony to his lasting impact, and it is most fitting that this issue of the JA has been devoted to his memory.

\section{CONFLICT OF INTEREST}

The author declares no conflict of interest.

Gordon Cragg NIH Special Volunteer, Natural Products Branch, Developmental Therapeutics Program, Division of Cancer Treatment and Diagnosis, National Cancer Institute, Bethesda, MD, USA E-mail: gmcragg2@gmail.com 